\title{
THE MINERALOGICAL STUDY ON THE CUEVA DE LAS VELAS (NAICA, MEXICO)
}

\author{
MINERALOŠKE RAZISKAVE JAME CUEVA DE LAS VELAS \\ (NAICA, MEHIKA)
}

\author{
Paolo FORTI ${ }^{1}$, Ermanno GALLI ${ }^{2}$, Antonio ROSSI ${ }^{2}$
}

\begin{abstract}
UDC 552.54:551.44(72)

Paolo Forti, Ermanno Galli \& Antonio Rossi: The mineralogical study on the Cueva de Las Vegas (Naica, Mexico)

The Cueva de las Velas is the last cave unveiled at -290 level within the Naica Mine; the cavity has been intercepted by a mine gallery at the beginning of 2005. One of its peculiarities is the widespread thick deposits of diagenetic minerals deposited over the cave walls before the beginning of the evolution of the giant gypsum crystals. These deposits consist of complex, often scarcely crystalline iron-manganese-lead oxides-hydroxides, but carbonates, sulphates and silicates are also present. Other minerals, mainly sulphates, started developing just after this area of the mine was dewatered some 20 years ago. Presently 17 different minerals have been observed, 5 of which (orientite, starkeyite, szmolnokite, szmikite and woodruffite) are completely new for the cavern environment. The study of these minerals, together with the presence of a completely new type of gypsum crystals, allowed to improve the knowledge on the speleogenetic evolution of this cave, which seems to be by far more complex than that of the other cavity of the -290 level. Its complexity is reflected by the activity of a larger number of different speleogenetic mechanisms. Among them are worth of mention the thermal corrosion/dissolution, the anhydritegypsum disequilibrium, the acid aggression, and the capillary migration and evaporation.
\end{abstract}

Keywords: Mine caves, cave minerals, speleogenetic mechanisms, Mexico.
Izvleček

UDK 552.54:551.44(72)

Paolo Forti, Ermanno Galli \& Antonio Rossi: Mineralološke raziskave jame Cueva de Las Vegas (Naica, Mehika)

Cueva de las Velas je zadnja odkrita jama na nivoju -290 v rudniku Naica. Votlina je je v začetku leta 2005 presekala rudniško galerijo. Ena od zanimivosti jame je razširjenost diagenetskih mineralov, ki na debelo odloženi na jamskih stenah pred razvojem kristalov sadre. Te obloge so iz kompleksnih, le redko kristalioziranih železo-mangano-svinčevih hidroksidov s prisotnostjo karbonatov, sulfatov in silikatov. Rast ostalih, v glavnem sulfatnih mineralov, se je začela takoj po odvodnjavanju tega dela rudnika pred 20 leti. Do sedaj smo našli 17 različnih mineralov, od katerih je pet takih, ki so bili prvič najdeni $\mathrm{v}$ jamskem okolju. Raziskave teh mineralov, so poleg prisotnosti povsem novih vrst kristalov sadre, omogočile nova spoznanja o speleogenezi te jame. Ta je verjetno precej bolj kompleksna od geneze ostalih jam na tem nivoju (-290), saj so ji botrovali različni speleogenetski mehanizmi, kot npr. termalna korozija, neravnotežje sistema sadra/anhidrit, delovanje različnih kislin, ter kapilarna migracija in izhlapevanje.

Ključne besede: jame v rudnikih, jamski minerali, speleogenetski mehanizmi, Mehika.

\footnotetext{
${ }^{1}$ La Venta Exploring Team \& Istituto Italiano di Speleologia, paolo.forti@ unibo.it

${ }^{2}$ Dipartimento di Scienze della Terra, Università di Modena e Reggio Emilia

Received/Prejeto: 22.08.2007
} 


\section{INTRODUCTION}

The systematic study of "mine caves" has emphasized the high scientific interest of the minerogenetic processes active therein (De Waele \& Naseddu, 2005; Forti et al., 2005).

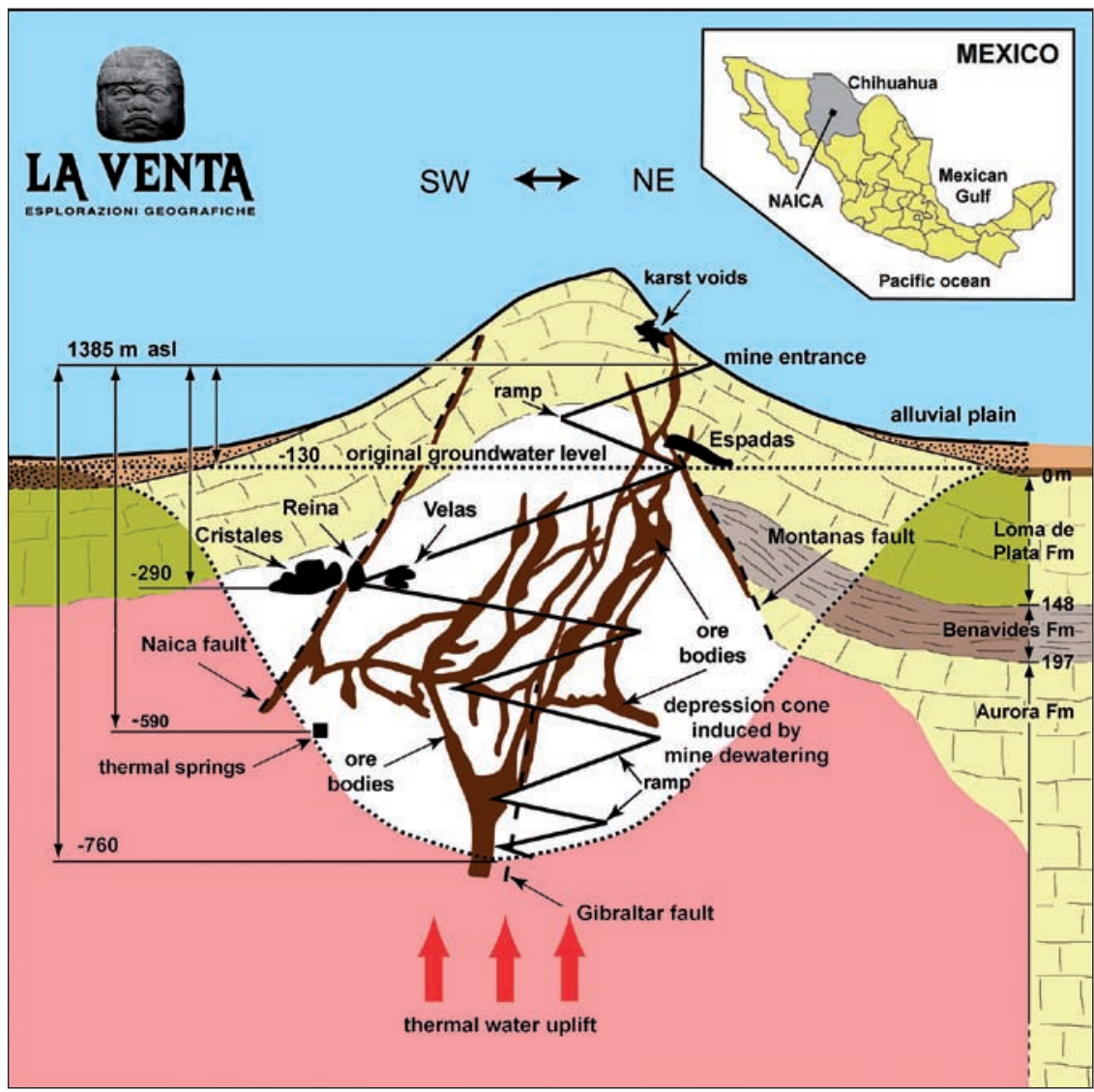

Fig. 1: Sketch of the Naica mine with the locations of the main natural cavities: on the right the stratigraphic sequence as derived by a $1150 \mathrm{~m}$ long drilling (after Badino \& Forti, 2007, modified).

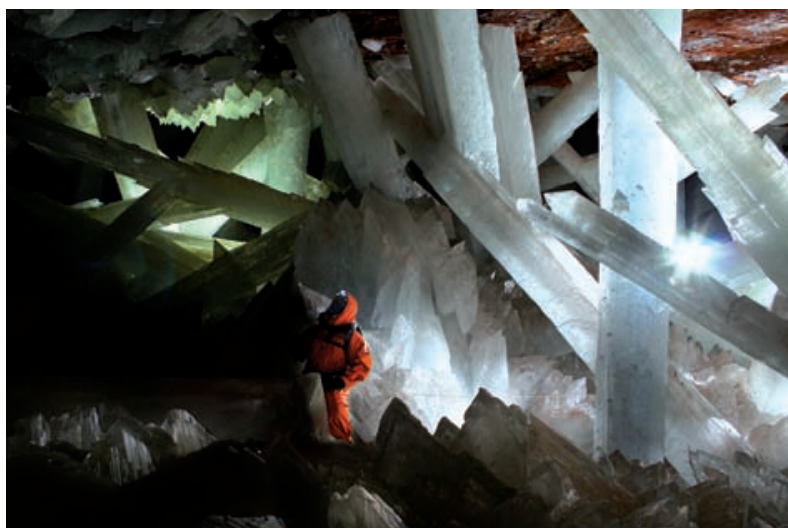

Fig. 2: General view of the giant gypsum crystals (caver for scale) (photo Archive Speleoresearch \& film and La Venta Exploring team).
From this point of view, the natural cavities crossed by mine galleries in Naica (Chihuahua, Mexico) (Fig. 1) have been world renowned for over a century, due to the dimension and purity of their gypsum crystals (Hill \& Forti, 1997) (Fig.2).

Beside Cueva de las Espadas (Swords cave), unveiled at the beginning of the 20th century at the -120 level, where crystals up to 2 meters in length exist (Degoutin, 1912; Foshag, 1927). In the last 5-6 years mine galleries at the -290 level have intercepted several natural cavities, the most important of which are Cueva de los Cristales (Crystal Cave), Ojo de la Reina (Queen's Cave) (Shangun, 2001) and Cueva de las Velas (Sails Cave) (Fig. 3). All these caves host gypsum crystals much bigger that those in the Cave of the Swords, but there are many other features worthy of study (Forti, 2006).

The Cueva de las Velas is the latest large mine cave found at Naica. This cavity was intercepted in 2005 and it was explored and mapped by La Venta Exploring Team in April 2006 (Badino \& Forti, 2007).

The cave, which has a total length of about $80 \mathrm{~m}$, is oriented north-south and consists of two main large rooms partially superimposed (Fig. 3). The average high of the chambers is 3-4 m, while their width is often over $10 \mathrm{~m}$.

Cueva de las Velas immediately proved to be extremely interesting due to peculiarity of the hosted chemical deposits. What makes this cavity absolutely special is the presence of many small, thin and very delicate speleothems (the sails), developed on top of the gypsum crystals in the upper room of the cave (Fig. 4) (Bernabei et al., 2006), but this is not the single peculiarity of Cueva de la Velas. In fact it is the single cavity in which most of the carbonate rock, whether covered or not by gypsum crystals, is overlain by a thick (up to $20-50 \mathrm{~cm}$ ) deposit of metallic oxides-hydroxides (Fig. 5). These deposits are much more frequent and thick in the lower room, which therefore exhibits a much darker aspect.

The present study is focused on the minerals of these deposits and it is a part of a general research project 


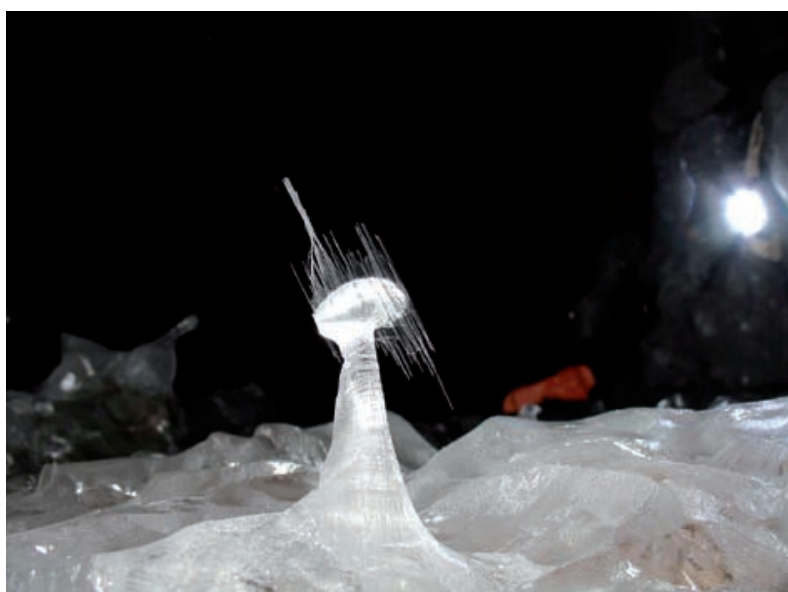

Fig. 4: A characteristic gypsum crystal (called "vela", sail), which gave the name to the Cueva de las Velas (Photo Archivio La Venta \& $S / F)$.

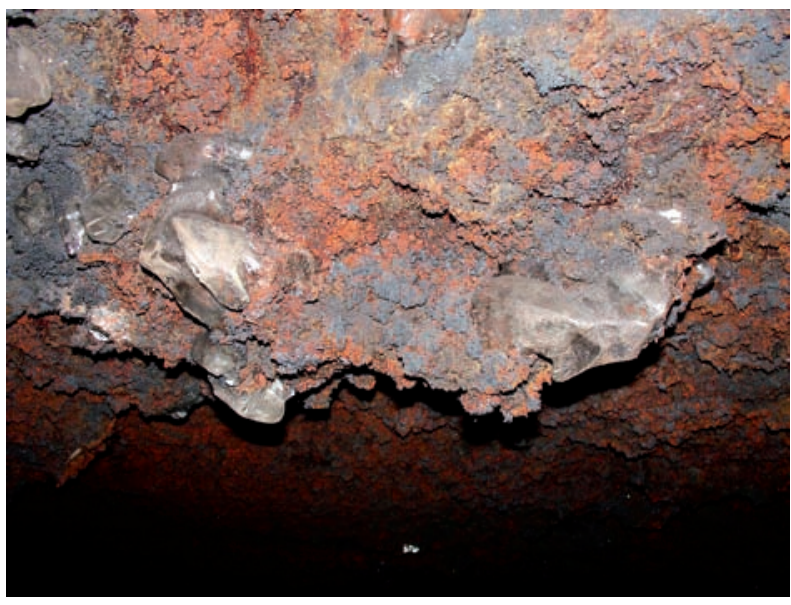

Fig. 5: A portion of the cave wall in which a thick deposit of metallic oxides-hydroxides are exposed (Photo Archivio La Venta \& $/ F)$.

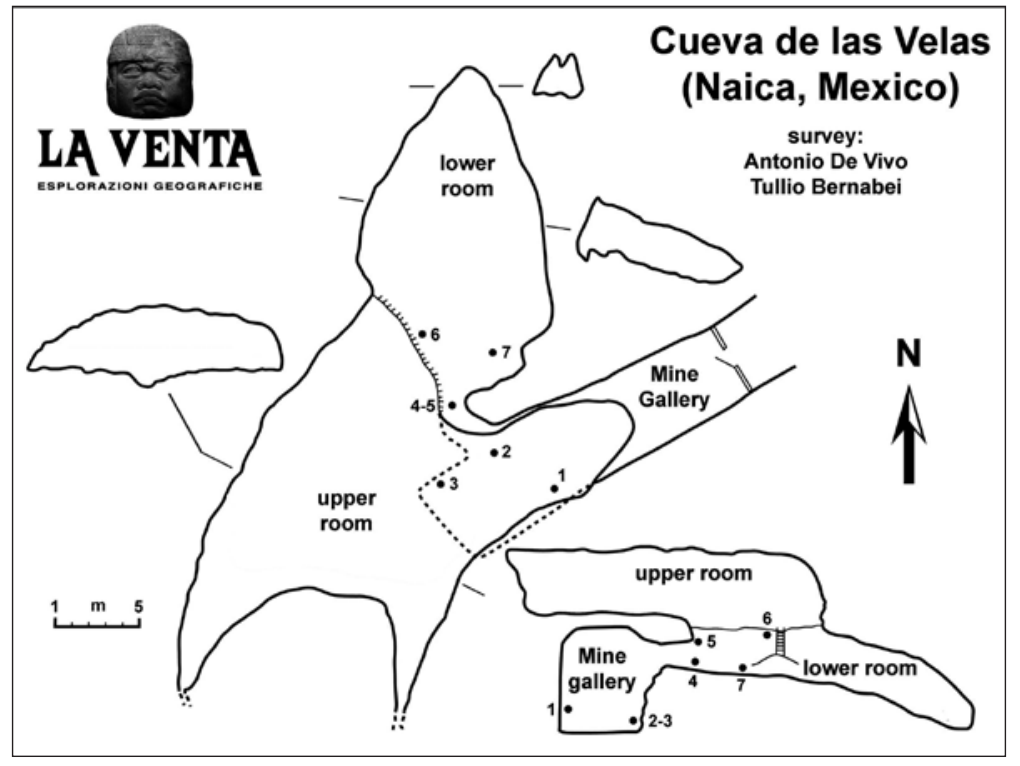

which the owner of the mine, the Peñoles Company, decided to commit to La Venta Exploring Team from Italy and Speleoresearch \& Films of Mexico City in 2006 (Forti, 2006).

Fig. 3: Plan and vertical sections of the Cueva de las Velas with the sample locations.

\section{EXPERIMENTAL OBSERVATIONS}

The general geology, the structure and the ore evolution of Naica region is well known and documented (Stone, 1959; Megaw et al., 1988; Lang, 1995; García-Ruiz et al., 2007), therefore it would be useless to discuss them in detail.

The Naica mine opens on the north-western side of a $12 \mathrm{~km}$ long and $7 \mathrm{~km}$ wide dome-shaped structure NW-SE oriented and affected by secondary foldings, faults and erosion.

This structure has an average height of $1700 \mathrm{~m}$ above sea level and is formed, almost entirely, by calcare- ous rocks (limestone, dolomitic limestone and carbonate dolostone) that have settled during a dozen million years, starting from the Albian (125 Myr BP).

The sulphides mineralization ( $\mathrm{Pb}, \mathrm{Zn}$ and $\mathrm{Ag}$ ) has formed due to hydrothermal circulation, produced by tertiary dykes(26,2-25,9 My) some $3 \mathrm{~km}$ below the Naica surface.

The structural control over the arrangement of the mineralized masses, the water circulation and the karst development was exerted by a system of faults and frac- 


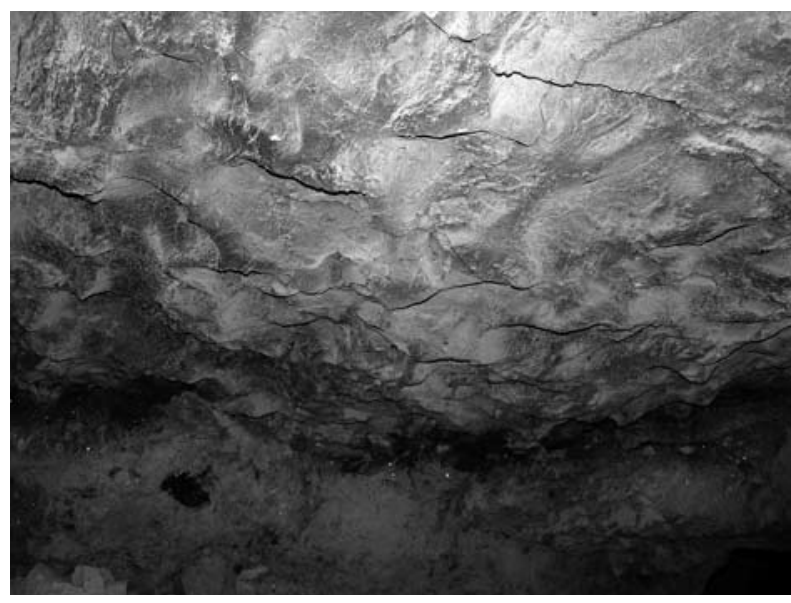

Fig. 6: Limestone ceiling of the cave close to the entrance where small corrosion domes induced by acid aggression developed (Photo Archivio La Venta \& S/F).

tures, parallel to the longer axis of the dome, NW-SE oriented and dipping towards SW all the way to verticality (Fig. 1). Finally, the mining area is still under thermal anomaly: the water that spurts into the mine bottom reaches a temperature close to $59^{\circ} \mathrm{C}$.

The morphology of the few parts of the Cueva de las Velas free of gypsum crystals shows that karst evolution was mainly controlled by bedding planes, while, at least in one developing stage before the deposition of gypsum, acid aggression induced by sulphide oxidation was the main corrosion factor (Fig. 6).

Nine samples were taken from seven spots in the wall of the cave where the primary minerals have been transformed to give rise to alteration compounds: all of them were taken in the lower part of the caves where the widespread lack of gypsum cover allows an easy choice (Fig. 3).

Four samples were obtained by scratching the inner part of three wall fractures in the mine gallery (spots 1,2, 3 of Fig. 3) which are clearly connected with the cave and in one fracture (spot 6 of Fig. 3) in the wall between lower and upper part of the cavity. Inside all these fractures there were clear evidences of active diagenesis, probably induced by hydration and/or oxidation due to the presence of an atmosphere as a consequence of mine dewatering since 17 years. All these samples consist of rock fragments (calcite and/or dolomite 1 and 2; and gypsum 3 and 6) covered by alteration material. One side of sample 1 is covered by a thin film of spheroid aggregates of small scalenohedral semitransparent calcite crystals, which are in turn partially covered by greyish powder. The other side is covered by a deposit of grey to reddish earthy material. Both sides of sample 2 are covered by thin silver shining cauliflower shaped very fragile blades, which loose their shining and turn into earthy coal black
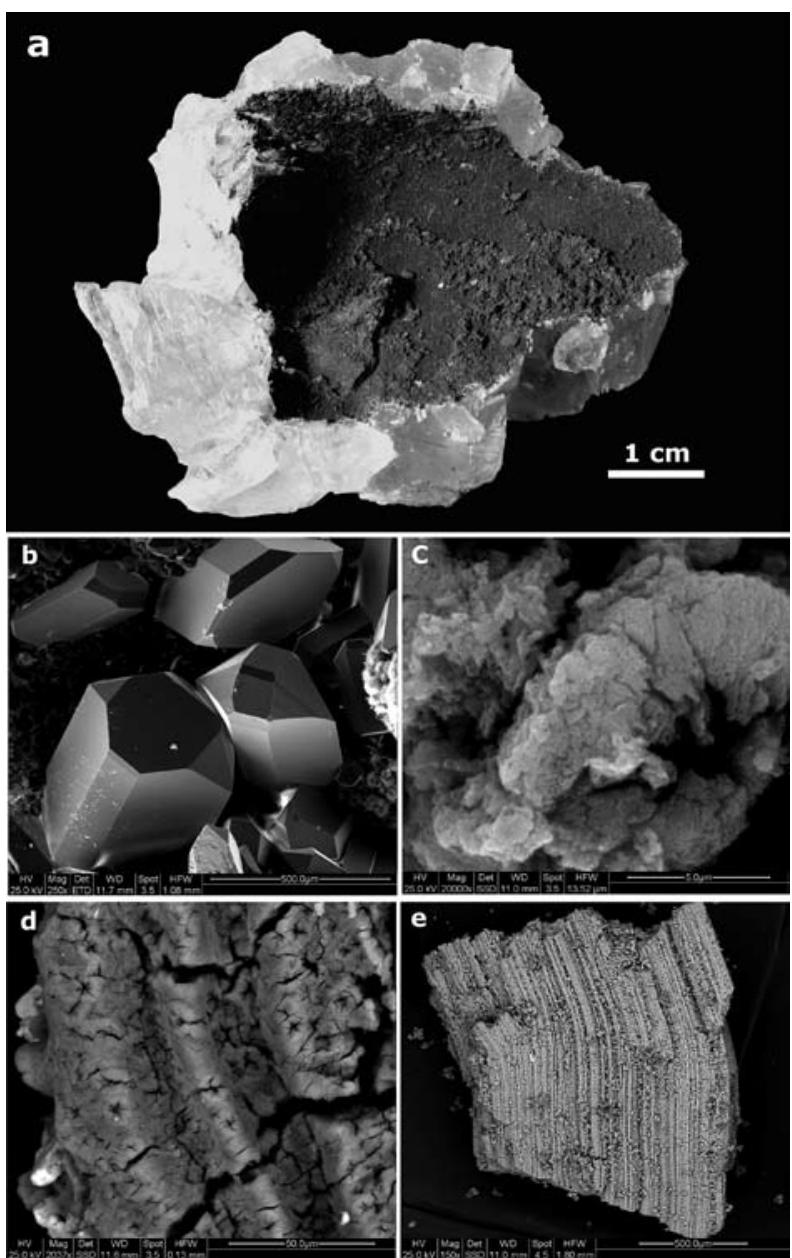

Fig. 7: a) Lower surface of gypsum mega-crystals incrusted by a dark grey to reddish brown thin scarcely cemented powder; ESEM images: b) well formed transparent celestine crystals; c) toroidal grain of earthy milky white rozenite; d) whitish earthy hard aggregate of starkeyite; e) layered structure of thin films rich in rozenite and starkeyti.

powder when scratched. Both samples from spot 3 and 6 consist of gypsum fragments covered by an earthy deep grey, cinder like, powder very similar to that of sample 2 even if with bigger grains.

Because these four samples have similar textural and structural characteristics (thin powder from white to greyish to pale brown) and evidenced similar mineralogical composition, they have been considered as a single sample, referred as Wf (wall fractures) in Table 1.

The other five samples came from the thick black deposit underlying the gypsum crystals and were taken in the spots 4, 5, 7 of Fig. 3. All of them consist of black, shining black, red to reddish-brown, earthy yellow, sometimes partially cemented powder (Fig. 7a). Always inside the powder there are several small transparent sub-millimetric sized crystals. Due to their rather constant mor- 
Tab. 1. Cave minerals of Cueva de Las Velas (Naica)

\begin{tabular}{|c|c|c|c|c|c|c|}
\hline Sample type & Mineral & Chemical formula & System & Group & Fig. No & References $^{1}$ \\
\hline Wf & Anglesite & $\mathrm{PbSO}_{4}$ & Orth. & Barite & & HB 5, 24 \\
\hline Wf-Bd & Celestine & $\mathrm{SrSO}_{4}$ & Orth. & $"$ & $7 b ; 9 f$ & HB 5, 122 \\
\hline Wf & Szmolnokite* & $\mathrm{FeSO}_{4} \cdot \mathrm{H}_{2} \mathrm{O}$ & Mon. & Kieserite & & HB 5, 688 \\
\hline Wf & Kieserite & $\mathrm{MgSO}_{4} \cdot \mathrm{H}_{2} \mathrm{O}$ & Mon. & $"$ & & HB 5, 358 \\
\hline Wf & Szmikite* & $\mathrm{MnSO}_{4} \cdot \mathrm{H}_{2} \mathrm{O}$ & Mon. & $"$ & & HB 5, 687 \\
\hline$W f-B d$ & Gypsum & $\mathrm{CaSO}_{4} \cdot 2 \mathrm{H}_{2} \mathrm{O}$ & Mon. & & $9 e ; 9 f$ & HB 5, 271 \\
\hline Wf & Rozenite & $\mathrm{FeSO}_{4} \cdot 4 \mathrm{H}_{2} \mathrm{O}$ & Mon. & Rozenite & $7 c, e$ & HB 5, 602 \\
\hline Wf & Starkeyite* & $\mathrm{MgSO}_{4} \cdot 4 \mathrm{H}_{2} \mathrm{O}$ & Mon. & $"$ & $7 d, e$ & HB 5, 663 \\
\hline Wf & Jarosite & $\mathrm{K}_{2} \mathrm{Fe}_{6}^{3+}\left(\mathrm{SO}_{4}\right)_{4}(\mathrm{OH})_{12}$ & Trig. & Alunite & $8 a$ & HB 5, 330 \\
\hline Wf-Bd & Calcite & $\mathrm{CaCO}_{3}$ & Trig. & Calcite & & HB 5, 101 \\
\hline Wf & Dolomite & $\mathrm{CaMg}\left(\mathrm{CO}_{3}\right)_{2}$ & Trig. & Dolomite & & HB 5, 191 \\
\hline Wf-Bd & Goethite & $\mathrm{a}-\mathrm{Fe}^{3+} \mathrm{O}(\mathrm{OH})$ & Orth. & & $8 d, e, f ; 8 e$ & HB 3, 223 \\
\hline Wf & Fluorite & $\mathrm{CaF}_{2}$ & Cub. & & & HB 3, 205 \\
\hline $\mathrm{Bd}$ & Coronadite & $\mathrm{Pb}\left(\mathrm{Mn}^{4+}, \mathrm{Mn}^{2+}\right)_{8} \mathrm{O}_{16}$ & Mon. & Cryptomelane & $9 a, b, c, d, e, f$ & HB 3, 138 \\
\hline Wf & Woodruffite* & $\mathrm{ZnMn}_{3} \mathrm{O}_{7} \cdot 2 \mathrm{H}_{2} \mathrm{O}$ & Tetr. & & $8 b$ & HB 3, 606 \\
\hline $\mathrm{Bd}$ & Opal & $\mathrm{SiO}_{2} \cdot \mathrm{nH}_{2} \mathrm{O}$ & Amor. & & & \\
\hline Wf & Orientite* & $\mathrm{Ca}_{2} \mathrm{Mn}_{2+} \mathrm{Mn}_{2}^{3+} \mathrm{Si}_{3} \mathrm{O}_{10}(\mathrm{OH})_{4}$ & Orth. & & $8 c$ & HB 2/2, 602 \\
\hline
\end{tabular}

${ }^{1} \mathrm{HB}$ : Anthony et al. "Handbook of Mineralogy", Volume, Page.

* New cave mineral.

phology and mineralogical composition also these samples have been considered as a single one and referred in the Table 1 as Bd (Black deposit).

\section{EXPERIMENTAL METHODS}

A detailed analysis of all the samples by the stereoscopic microscope was performed to distinguish and to separate the different mineralogical phases present in each sample. Then the single phases were analysed by a powder diffractometer (Philips PW 1050/25), when the material was quantitatively enough and homogeneous, or by a Gandolfi camera (Ø: $114.6 \mathrm{~mm}$, exposition: 24/48 hrs), when the material was scarce or inhomogeneous. Always the experimental conditions were: $40 \mathrm{Kv}$ e $20 \mathrm{~mA}$ tube, $\mathrm{CuKa}$ Ni filtered radiation $(\lambda=1.5418 \AA)$.

Rather all the samples analyzed by Gandolfi camera were later used to obtain images and chemical qualitative analyses through an electron scanning microscope (ESEM FEI Quanta 200) with an electronic microprobe (EDS Oxford INCA 350) at the C.I.G.S. (Centro Interdi- partimentale Grandi Strumenti) of the Modena and Reggio Emilia University.

\section{ANALYTICAL RESULTS}

The diagenetic minerals observed in the first group of samples (Wf) are by far the majority (see Tab. 1) and they consist mainly of hydrated sulphates, carbonates, oxides and silicates. Sample 1, and in particular its fraction consisting of cinder grey earthy material proved to be very interesting. In fact in this sample beside common cave minerals like celestine (Anthony et al., 2003c), one of the most abundant mineral which is present mainly as equant cross-section (Fig. 7b) but also as millimetric, perfectly transparent, well-formed lathlike crystals, tabular on $\{001\}$ and anglesite (Anthony et al., 2003a), there are also very rare hydrated sulphates of Fe like szmolnokite (Anthony et al., 2003m), and rozenite (Anthony et al., 2003h), of Mg come kieserite (Anthony et al., 2003g), and starkeyite (Anthony et al., 2003i),) and of Mn like szmikite (Anthony et al., 2003l). Three of them (szmol- 
nokite, starkeyite and smikite) are new for the cavern environment.

Rozenite (Fig. 7c) and starkeyite (Fig. 7d) are always deeply mixed together giving rise to millimetre sized, earthy, milky white spheres with a cotton ball wrinkled surface. Both these mineral are monocline and exhibit very similar crystallographic constants (rozenite: $\mathrm{a}_{\mathrm{o}}=$ $5.799 \AA, b_{o}=13.650 \AA ; c_{o}=7.977 \AA, \beta=90.43^{\circ}$; starkeyite: $\left.a_{o}=7.902 \AA, b_{o}=13.594 \AA ; c_{o}=5.920 \AA, \beta=90.89^{\circ}\right)$. Their X-ray powder diffraction patterns are rather coincident because the they are isostructural (Baur, 1960, 1961; Jambor \& Traill, 1963). Therefore their identification was possible only analysing the same samples of the Gandolfi camera by EDS microprobe on ESEM. Figure $6 e$ shows alternating bands respectively rich in rozenite or in starkeyite.

It has been extremely difficult also to identify the three monohydrated sulphates szmolnokite $\left(\mathrm{FeSO}_{4} \cdot \mathrm{H}_{2} \mathrm{O}\right)$, kieserite $\left(\mathrm{MgSO}_{4} \cdot \mathrm{H}_{2} \mathrm{O}\right)$ and szmikite $\left(\mathrm{MnSO}_{4} \cdot \mathrm{H}_{2} \mathrm{O}\right)$. They were undistinguishable at the stereo-microscope, because all these three minerals give rise to small earthy aggregates of micrometric crystals with slightly different colours (pale brown masses: szmolnokite; milky white, greasy spheres: kieserite; botryoidal milky white to pale pink masses: szmikite). Therir X-ray powder diffraction are very similar, because all the three minerals belongs to the same group and have similar crystallographic constants (szmolnokite: $\mathrm{a}_{\mathrm{o}}=7.624 \AA$, $\mathrm{b}_{\mathrm{o}}=7.468 \AA ; \mathrm{c}_{\mathrm{o}}=7.123$ $\AA, \beta=115.9^{\circ}$; kieserite: $a_{0}=7.511 \AA, b_{0}=7.611 \AA ; c_{0}=$ $6.921 \AA$, $\beta=116.17^{\circ}$; szmikite: $a_{0}=7.766 \AA$, $b_{o}=7.666 \AA$; $\left.c_{0}=7.120 \AA, \beta=115.85^{\circ}\right)$. Their identification was made by chemical analyses performed on the same samples used for the X-ray diffraction: szmolnokite and szmikite proved to be very rare and have been identified surely only once, while kieserite is much more abundant.

Jarosite, (Anthony et al., 2003f) the iron hydroxylsulphate belonging to the alunite group, is rather common as earthy lemon yellow soft crumbly grains (Fig. $8 a)$ or as minutely crystalline crust over metallic grains over which often diagenetic calcite and dolomite may be found.

Woodruffite (Anthony et al., 1997d), a compound which is characteristic of the oxidized zone of $\mathrm{Ag}-\mathrm{Pb}-\mathrm{Zn}$ deposits, has been here reported for the first time as cave mineral. It is anyway very rare and it occurs as tuffs of thin small, silver shining to old gold yellow, blades (Fig 8b).

The last of the five new cave minerals, orientite (Anthony et al., 1995), is a Mn and Ca hydrous silicate present as thin silver blades, which at higher enlargement proved to be tuffs of thin acicular crystals (Fig. 8c): it is always mixed to woodruffite and they were found exclusively in a small lens filling a crack of the sample taken in the wall fracture close to the spot 2 .
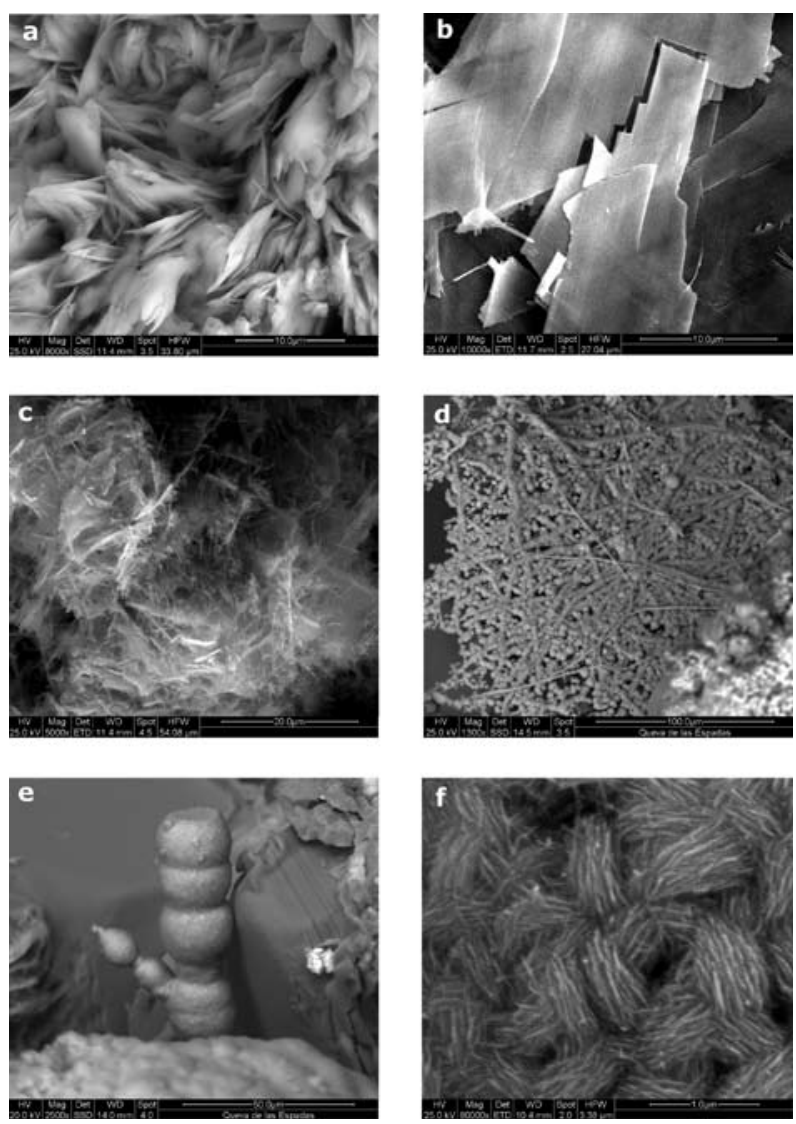

Fig. 8: ESEM images: a) detail of a earthy lemon yellow globular aggregate of jarosite; $b$ ) thin emi-transparent tabular crystals of woodruffite; c) tuffs of acicular silver grey to gold shining orientite crystals; d) thin layer of goethite reddish-brown to dark grey micro-spheres: most of them are empty inside, clearly fossilizing biological masses; e) strange aggregate of goethite micro-spheres; f) detail of the structure of the goethite consisting of thin small blades resembling a wool skein.

A few minerals (celestine, gypsum, calcite and goethite) are common to both the sample types (Wf and Bd). Goethite (Anthony et al., 1997c), is by far the most common and widespread compound. It is normally scarcely crystalline and occurs normally as sub-millimetric partially empty spheres. The outer part is reddish-brown to black while the inner part consist of earthy red aggregates. The ESEM-EDS analyses evidenced the presence of tuffs of filaments consisting of a sequence of micro-spheres of different size which give rise to complex dendritic structures (Figgs. 8d, e, f): it is evident that goethite fossilized biogenic structures, probably those responsible for the oxidation of the ore bodies.

Coronadite (Anthony et al., 1997a), is the most peculiar and rare mineral of the $\mathrm{Bd}$ samples. This $\mathrm{Pb}$ and $\mathrm{Mn}$ oxides is rather common within the South America ore bodies even if it was rarely well-characterized. Its name comes from the first Spanish explorer of the American 
southwest, Francisco Vasquez de Coronado. Coronadite was described as cave mineral only recently from a single cave, Santa Barbara mine cave, Italy (Forti et al., 2005). In Cuevas de las Velas it occurs as: a) radial aggregates (Fig. 9a) of microscopic tabular blades with colour changing from shining gold yellow at the bottom to shining silver grey at the top; or b) as earthy soft deep grey to reddish material. At strong enlargement (Fig. 9b) the tabular blades of the radial aggregates consist of a thick network of thin elongated iso-oriented micrometric crystals (Fig. 9c), while fibrous radial aggregates of prismatic crystals, far shorter than the previous ones, constitute the earthy material (Fig. 9d).

In a single sample it was possible to detect opal as small spheres often growing over the Fe- oxides-hydroxides.
From paragenetic point of view no deposition sequence can be defined within the Wf samples: it is therefore highly probable that all the 15 different minerals are presently growing simultaneously.

On the contrary the Bd samples evidenced a clear depositional sequence. Goethite and coronadite are the more abundant and first deposited minerals, then opal and calcite started forming just when the deposition of the oxides was close to the end. After that euhedral celestine crystals started to develop thus covering the pre-existing minerals. Finally when the deposition of celestine was over gypsum begun to form, later giving rise to the development of the giant gypsum crystals.

\section{DISCUSSION}

From the mineralogical point of view the black deposits show a far lower variability ( 6 minerals) if compared with that of the samples coming from the cave walls fractures (15 minerals). Moreover only two minerals are peculiar of the black deposits (coronadite and opal), while the other 4 are present also in the cave wall fractures. Among the six minerals of the black deposits 5 are very common: only coronadite may be considered a "rare" cave mineral, having been detected until now in a single cavern environment (Forti et al., 2005).

The strong oxidation processes of the ore bodies are testified by the thickness of the black deposits and by the huge amounts of biogenic structure fossilized inside them. Anyway the scarcity of mineral variability within the black deposits are clearly a direct consequence of the fact that these processes occurred within a huge thermal reservoir, where no sharp variation of $\mathrm{pH}$, nor supersaturation with respect to soluble salts may be induced by oxidizing processes.

While goethite and coronadite are direct products of these processes, the opal formation was induced by a even scarce $\mathrm{pH}$ lowering caused by the oxidation of the $\mathrm{H}_{2} \mathrm{~S}$ to $\mathrm{H}_{2} \mathrm{SO}_{4}$. Later, the increase of $\mathrm{SO}_{4}^{2-}$ caused the supersaturation with respect to Celestine and after to gypsum, thus confirming the mineralogical sequence of Figure $9 f$.

Finally calcite is always very rare and it is present as small aggregates of crystals with complex shapes: its origin was likely controlled by variation in the activity of the biogenic masses ruling the oxidation of the ore bodies, which caused simultaneous variation in $\mathrm{CO}_{2}$ concentration within the thermal water.
The number of minerals (15) present in the powder scratched from the cave wall and from its fractures is very high and testifies the minerogenetic efficiency of the oxidation processes of the primary minerals, dispersed in the host rock, induced by the presence of an atmosphere. Unlikely to those of occurred in the black deposits, the oxidation processes within the wall fractures are absolutely uncontrolled by microorganisms, and therefore no biomasses have been observed inside them.

All the wall fracture reactions occur within very small amount of condensation water, which is in turn subject to fast evaporation due to the forced ventilation of the mine. Therefore the supersaturation is reached not only for low solubility sulphates like anglesite, celestine, jarosite and gypsum, but also for some very soluble compound: it is the case of szmolnokite, kieserite, smikite, rozenite, and starkeyite. Moreover, in such an environment, the variation in the physico-chemical parameters is very high and the $\mathrm{pH}$ often reaches values close to 1 or 0 (Forti \& Salvatori, 1988; Forti \& Mocchiutti, 2004). This fact induces the deposition of minerals normally unstable in a cavern environment like jarosite.

In order to understand the deposition of rare and/or unusual minerals, another point has to be considered: the very short time span since the different minerogenetic reactions were active (less than 20 years). This fact justify the presence of only two crystalline oxide (goethite and woodruffite), while most of the iron and manganese is still in amorphous oxide-hydroxides compounds. Moreover the scarcity of time hindered many elements (in particular iron and manganese) to reach the highest possible oxidation, thus inducing the deposition of minerals in 

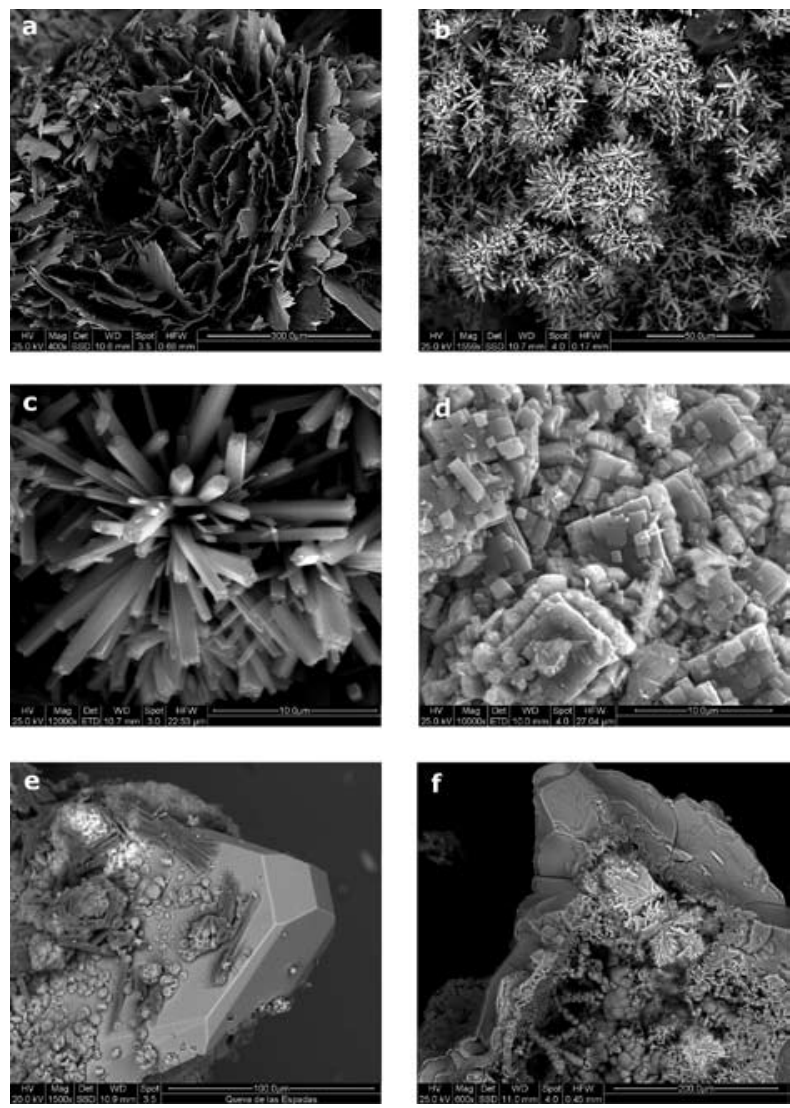

which these elements have a lower valence (i.e. szmolnokite, smirkite, rozenite, coronadite, orientite).

The presence of calcite and, with a biogenic mediation, of dolomite is the normal consequence of $\mathrm{CO}_{2}$
Fig. 9 - ESEM images: a) flower consisting of thin bended blades of coronadite, the color of which is gold yellow at the basis and shining silver on top; $b$ ) radial tuffs of small prismatic acicular crystals of coronadite; $c$ ) detail of a coronadite tuff showing the quadrate section of the prismatic crystals; d) detail of the earthy coronadite structure; e) transparent prismatic tabular celestine crystals with overgrowth of iso-oriented acicular gypsum crystals and goethite micro-spheres; f) Small opale cavity covered by filaments and micro-spheres of goethite on the left, and dendritic aggregates of coronadite on the right.

diffusion in a solution saturated with respect to gypsum (Forti et al., 2007; Vasconcelos et al., 1995).

Finally the fast evaporation of small volumes of water may be the cause of the deposition of fluorite, the fluorine ions coming from the widespread fluorite within the mineralised masses.

It is not possible to give a depositional chronology, like that obtained for the black deposits, for the samples scratched from the cave walls: this because each powder grain is composed by a single mineral or, eventually, by the minerals of the same group.

It is highly probable that the number of the mineral actually forming within the fractures of this cave should be higher, in fact a preliminary mineralogical analysis performed over a few scratched samples from fractures of the Ojo de la Rejna cave (a few tens of meter far from Cueva de las Velas) evidenced the presence not only of several already observed minerals (gypsum, starkeyite, calcite, coronadite) but also of four new ones (bloedite, quartz, bassanite, and epsomite).

\section{STAGES IN THE DEVELOPMENT OF THE CAVE}

On the basis of the actual knowledge on the mineralogy of the Cueva de las Velas it is now possible to reconstruct the main evolutionary steps, the cavity underwent from its genesis up to the present days.

Its first stage of development, which must be clearly contemporary to that of the other 3 caves of Naica, has to be referred to thermal water uplift along the main faults, which, still now, are responsible for the water circulation inside the Naica structure.

These faults partially displaced the mineral deposits and therefore they are far younger than the ore bodies, which started to develop 26,2-25,9 My BP (Megaw et al., 1988).

The existence inside the ore bodies of different kinds of fluid inclusion with temperature ranging from 680 to $130^{\circ} \mathrm{C}$ (Erwood et al., 1979) suggest that, until the tem- perature of the thermal fluids was high, no karst void was developed: during all this period, in fact, the thermal fluids were in a condition of net deposition or at least of balance between deposition-corrosion processes, as confirmed by the scarcity and the small size of the open voids inside the mineral bodies. Surely the cooling down of the fluids lasted a very long time due to the fact that no external spring was related to them and the contribute of meteoric seepage scarce if any.

After the end of ore bodies development tectonic movements took place causing the partial displacement of the mineral deposits: these displacements were controlled by the same faults which later allowed the water uplift which gave rise to the speleogenesis of the Naica caves and then the development of their gigantic gypsum crystals. 
Therefore the first stage of the karst development should have started only a few millions years BP, when the characteristics of the hot waters, with temperatures lower than $130^{\circ} \mathrm{C}$, allowed corrosion to prevail deposition.

This first stage of deep karst development was surely short and the corrosion process not very effective: in fact, the presently known caves are small and always they correspond to scarcely widened fractures (Ojo de la Reina and Cueva de las Espadas) or bedding planes (Cueva de las Velas).

After this first speleogenetic stage, which was common to all the 4 caves of Naica, their evolution was slightly different from each other, depending on local factors.

Cueva de las Velas was interested by widespread oxidation of sulphide minerals which were transformed into oxides-hydroxides: this process was clearly controlled by micro-organisms, as testified by widespread biogenic structures preserved within the deposits (Fig. 8d.e).

During this stage, while a thick black deposit covered the cave floor and most of its walls, the roof clearly underwent acid aggression as testified by the corrosion cupolas still visible in the first part of the cavity (Fig. 6).

During the latest stage of oxides-hydroxides deposition, the uplifting water became oversaturated with respect to celestine and, later, with respect to gypsum: this sequence is clearly recorded in the black deposit as shown by ESEM-EDS (Fig. 9f).

The appearance of gypsum crystals is an indirect proof that the temperature of the thermal water reached a value lower than $59^{\circ} \mathrm{C}$, because above this value anhydrite should be the single forming mineral (García-Ruiz et al., 2007).

When the sulphide oxidation was over, the development of the giant gypsum crystals started: this pro- cess was completely controlled by the anhydrite-gypsum equilibrium and the needed calcium sulphate was provided by the slow dissolution of the anhydrite lenses widespread within the host rock.

The existence of a lot of small gypsum crystals within the black deposits, which acted as crystallization nuclei, justifies the fact that, despite the new nucleation probability was extremely low (García-Ruiz et al., 2007) Cueva de las Velas is the single cave of Naica in which only a few of giant crystals developed, while most of its floor and walls are covered by a very high number of relatively small crystals ( $10-20 \mathrm{~cm}$ in size).

The gypsum deposition went on until, some 20 years ago, the mine exploitation caused the complete dewatering of the cave: anyway this fact did not represent the end of the development of the cave, which was characterized by two further steps.

The first one started just during the dewatering of the cave giving rise to the sails (Bernabei et al., 2006), but it stopped immediately after the cave was completely dried.

The latest stage, which is still active now, was induced by the presence of moist air, the condensation of which induced the diagenesis (oxidation) of some of the ore bodies exposed on the cave walls. This process, even extremely young and still in progress, allowed the development a large number of minerals, five of which are completely new for the cavern environment. Because this stage is induced by the direct contact between rock and air, it is highly probable that the same process is active also in other caves of the -290 level or even deeper within the Naica Mine: next investigation will test such an hypothesis.

\section{FINAL REMARKS}

The mineralogical study of the chemical deposits of Cueva de las Velas within the Naica mine has evidenced the existence in the cave history of two distinct periods in which several cave minerals were deposited mainly due to the oxidation of the ore bodies. In the first one, which occurred deep inside the thermal aquifer before the deposition of the giant gypsum crystals, a large quantity of material was deposited but, due to the scarce variability of such an environment, only a few minerals developed. The second one, which started under aerate conditions less than 20 years ago and it is still active now, induced the deposition of scarce material but with an extremely high mineralogical variability.

From this point of view the Cueva de Las Velas is an extremely important cave because it represent a natu- ral laboratory in which can be experimentally tested the boundary conditions for the development of several even extremely rare cave minerals.

Unfortunately this cave, as all of the other karst phenomena at the -290 level of Naica mine will remain visible only for a few years, and as soon as the mining activities will stop (an event that is expected within 7-10 years), the uplifting of groundwater will submerge them under some $170 \mathrm{~m}$ of water. It is therefore important that all the studies still in progress on Naica and its incredible mine caves will be completed in the shortest possible time in order to preserve for future generations at least a full knowledge of these astonishing natural phenomena. 


\section{ACKNOWLEDGEMENTS}

The Authors thanks Peñoles Company for allowing the access inside the Naica Mine and for any kind of help given during the field work, Roberto Villasuso for the useful geological discussions and doctor Pier Luigi Fabbri of the
"Centro Interdipartimentale Grandi Strumenti (C.I.G.S.) of the University of Modena and Reggio Emilia for the precious help in the ESEM-EDS analyses.

\section{REFERENCES}

Anthony J.W., R.A. Bideaux, K.W. Bladh, \& M.C. Nichols, 1995: Handbook of Mineralogy - Vol. II (Silica, Silicates). - Mineral Data Publishing, Tucson, Arizona.

Anthony J.W., R.A. Bideaux, K.W. Bladh, \& M.C. Nichols, 1997: Handbook of Mineralogy - Vol. III (Halides, Hydroxides, Oxides). - Mineral Data Publishing, Tucson, Arizona: a)138; b) 205; c) 223.

Anthony J.W., R.A. Bideaux, K.W. Bladh, \& M.C. Nichols, 2003: Handbook of Mineralogy - Vol. V (Borates, Carbonates, Sulfates). - Mineral Data Publishing, Tucson, Arizona: a) 24; b) 101; c) 122; d) 191; e) 271; f) 330 ; g) 358 ; h) 602; i) 663 ; l) 687 ; m) 688 .

Baur, W.H., 1960: Die Kristallstruktur von $\mathrm{FeSO}_{4} \cdot 4 \mathrm{H}_{2} \mathrm{O}$. Naturwissenschaften, 47, 467.

Baur, W.H., 1961: Die Kristallstruktur des Leonhardtits, $\mathrm{MgSO}_{4} \cdot 4 \mathrm{H}_{2} \mathrm{O}$, und des Rozenits, $\mathrm{FeSO}_{4} \cdot 4 \mathrm{H}_{2} \mathrm{O}$. Forts. Min., 39, 333-334.

Badino G. \& P. Forti, 2007: The Exploration of the Caves of the Giant Crystals (Naica, Mexico) NSS News 65 (2), 12-18.

Bernabei T., P. Forti, \& R. Villasuso, 2006: A new type of gypsum crystal from Naica (Mexico). Int. J. of Speleology 36(1), 23-30.

De Waele J. \& A. Naseddu (Ed.), 2005: Le grotte di miniera tra economia mineraria ed economia turistica. IIS Mem. XVII.

Degoutin N., 1912 : Les grottes a cristaux de gypse de Naica. Soc. Cient. Antonio Alzate Rev. 32, 35-38.

Erwood, R.J., S.E. Kesler, \& P.L. Cloke, 1979: Compositionally distinct, saline hydrothermal solutions, Naica Mine, Chihuahua, Mexico. Economic Geology 74, 95-108.

Forti P., 2006: Una foresta di cristalli di gesso nel profondo della miniera di Naica. Geoitalia 18, 29-34.

Forti P. \& A. Mocchiutti, 2004: Le condizioni ambientali che permettono l'evoluzione di speleotemi di zolfo in cavità ipogeniche:nuovi dati dalle grotte di Capo Palinuro (Salerno, Italia). Grotte d'Italia 5, 4 (2003), 39-48.

Forti P. \& S. Salvatori, 1988: Nuovi minerali di grotta: la fibroferrite di Grotta Ferrata. Riv. Mineral. Italiana $1988,4,219-226$.

Forti P., E. Galli, \& A. Rossi, 2006: Peculiar minerogenetic environments: the Cuatro Ciénegas karst area (Cohauila, Mexico) Acta Carsologica 35,1, 79-98.

Forti P., E. Galli, \& A. Rossi, 2007: Il sistema Gesso-Calcite-Aragonite: nuovi dati dalle concrezioni del Livello -570 della Miniera di Naica (Messico). Congr. Naz. Speleol., Iglesias, in press.

Forti P., A. Pagliara, E. Galli, A. Rossi, J. De Waele, A. Naseddu, \& S. Papinuto, 2005: Studio morfologico e mineralogico di dettaglio del concrezionamento del sistema carsico di Santa Barbara (Miniera di San Giovanni). Atti Simposio "Le grotte di miniera tra economia mineraria ed economia turistica", Iglesias 2004, IIS Mem. XVII, 57-68.

Foshag, W., 1927: The selenite caves of Naica, Mexico. Amer. Mineral., 12, 252- 232.

García-Ruiz J.M., R. Villasuso, C. Ayora, A. Canals, \& F. Otálora, 2007: The Formation of Gypsum Megacrystals. Geology 35,4, 327-330

Hill C.A. \& P. Forti, 1997: Cave minerals of the World. National Speleological Society, Huntsville.

Jambor, J.L. \& R.J. Traill, 1963: On rozenite and siderotil. Canad. Mineral. 7, 751-763.

Lang, J.R., 1995: A geological evaluation of the Naica deposit, Chihuahua, Mexico. Internal Report of Compañia Fresnillo. 109 pp.

Megaw, P.K.M., J. Ruiz, \& S.R. Titley, 1988: High-temperature, carbonate-hosted $\mathrm{Pb}-\mathrm{Zn}-\mathrm{Ag}(\mathrm{Cu})$ deposits of northern Mexico. Economic Geology 83, 1856-1885.

Shagun C.L., 2001: Naica's subterranean Marvels. NSS News 59, 6, 166-169.

Stone, J.G., 1959: Ore genesis in the Naica District, Chihuahua, Mexico. Economic Geology 54, 1002-1034.

Vasconcelos C., J.A. Mckenzie, S. Bernasconi, D. Crujic, \& A. Tiens, 1995: Microbial mediation as a possible mechanism for natural dolomite formation at low temperature. Nature 377, 220-222. 